2016-12

\title{
An advanced micro-bio-loop to produce biogas
}

Jin, $Q$

http://hdl.handle.net/10026.1/17719

10.1016/j.jclepro.2016.08.136

Journal of Cleaner Production

Elsevier BV

All content in PEARL is protected by copyright law. Author manuscripts are made available in accordance with publisher policies. Please cite only the published version using the details provided on the item record or document. In the absence of an open licence (e.g. Creative Commons), permissions for further reuse of content should be sought from the publisher or author. 


\section{Accepted Manuscript}

An advanced micro-bio-loop to produce biogas

Qiang Jin, Alistair G.L. Borthwick

PII: S0959-6526(16)31300-2

DOI: $\quad$ 10.1016/j.jclepro.2016.08.136

Reference: JCLP 7928

To appear in: Journal of Cleaner Production

Received Date: 5 July 2016

Revised Date: 25 August 2016

Accepted Date: 26 August 2016

Please cite this article as: Jin Q, Borthwick AGL, An advanced micro-bio-loop to produce biogas, Journal of Cleaner Production (2016), doi: 10.1016/j.jclepro.2016.08.136.

This is a PDF file of an unedited manuscript that has been accepted for publication. As a service to our customers we are providing this early version of the manuscript. The manuscript will undergo copyediting, typesetting, and review of the resulting proof before it is published in its final form. Please note that during the production process errors may be discovered which could affect the content, and all legal disclaimers that apply to the journal pertain. 
4

5

6

7

8

\section{An Advanced Micro-Bio-Loop to Produce Biogas}

Qiang $\operatorname{Jin}^{1} *$ and Alistair G.L. Borthwick ${ }^{2}$

${ }^{1}$ School of Environmental Science and Engineering, Shanghai Jiao Tong University, No. 800, Dongchuan Road, Shanghai 200240, PR China

${ }^{2}$ Institute of Energy Systems, School of Engineering, The University of Edinburgh, The King's Buildings, Edinburgh EH9 3JL, UK

*Corresponding author

Qiang Jin

Phone: $+86-18621863638$

Fax: $+86-21-54740825$

Email address: qiang.jin@outlook.com

Abstract: The authors report an advanced micro-bio-loop that involves recycling through four steps; namely: microalgae culture; de-oxygenation; anaerobic digestion; and aerobic decomposition. The advanced micro-bio-loop operates under sunlight to produce a continuous stream of biogas without requiring any additional external input or internal output to its surrounds. In comparison to conventional biogas production process, it achieves a net positive energy balance at remarkably different level of $0.0224 \mathrm{kWh} \mathrm{MJ}^{-1}$, with less than $33 \%$ of environmental impacts, less than $0.57 \%$ of water demand, only $7.35 \%$ arable land-use and $0.041 \%$ of labor.

\section{Highlights}

- An advanced micro-bio-loop to produce biogas is proposed.

- The micro-bio-loop can break the bottlenecks of conventional biogas process.

- The overall performance is significantly improved by symbiotic coupling.

Keywords: biogas, microalga, biomass, biofuel, solar energy utilization 


\section{Introduction}

Biogas has outstanding versatility and high energy content. As a result, biogas presents an opportunity to reduce fossil-fuel dependence while contributing significantly to the sustainable development of rural areas. However, conventional biogas production (Fig. 1(a)) is often limited by problems related to the procurement and pre-treatment of feedstock, the post-treatment of digestate, and the storage and transportation of both feedstock and digestate (Lukehurst et al., 2010).

To overcome these problems, the authors propose and patent an advanced micro-bio-loop (CN103290059A) that involves recycling through four steps; namely: microalgae culture; de-oxygenation; anaerobic digestion; and aerobic decomposition (Fig. 1(b)). The advanced micro-bio-loop operates under sunlight to produce a continuous stream of biogas without requiring any additional external input or internal output to its surrounds. Our analysis demonstrates that the micro-bio-loop is much more energy-efficient and more competitive technologically, environmentally, and economically than an equivalent conventional biogas production system. These advances imply that the micro-bio-loop has succeeded in breaking the conventional biogas production mode, altering it from "open" to "closed", "complex" to "simple" and "sensitive" to "stable", with the potential to underpin a burgeoning, future biogas industry.

\section{Technological description of the advanced micro-bio-loop}

\subsection{Microalgae culture}

Single-celled microalgae biomass, promoted as an ideal third-generation biofuel feedstock (Cuellar-Bermudez et al., 2015), is employed in the advanced micro-bio-loop. Its productivity offers 10 20 times more biomass yield than terrestrial crops - after all, the mass of microalgae can double in as little as 24 hours (Clarens et al., 2010; Luque, 2010). Microalgae culture production can take place almost everywhere, obviating pressure on arable land, and thus greatly reducing food versus fuel concerns (Ashokkumar et al., 2015; Monari et al., 2016). The micro-bio-loop circumvents the need for continuous feedstock procurement, storage, and transportation. Microalgae suspension (which generally contains $0.5 \mathrm{~g} \mathrm{~L}^{-1}$ dry microalgae biomass) can easily reach a COD value 3 times higher than the industrial design threshold of $500 \mathrm{mgCOD} \mathrm{L}^{-1}$ (Milieuhygiëne and Foundation, 1989), and so anaerobic 
1 digestion can be undertaken directly without energy-intensive de-watering and concentration

2 pre-treatment steps.

32.2 De-oxygenation

4 The level of dissolved oxygen (DO) in microalgae suspension can easily reach up to five times

5 the air saturation value ( $\left.7 \mathrm{mgDO} \mathrm{L}^{-1}\right)$ (Jiménez et al., 2003; Mendoza et al., 2013), which is

6 much higher than the methanogenic limit of $0.1 \mathrm{mgDO} \mathrm{L}^{-1}$ according to Deubling and

7 Steinhauser (2011). For this reason, removal of dissolved oxygen is a critical procedure for the

8 next stage of anaerobic digestion. Various liquid-phase de-oxygenation techniques have been

9 employed in industry, including mechanical de-aeration, membrane-based de-oxygenation,

10 heating and chemical reduction (using a deoxidizer), etc. Crucially, these technologies are too

11 costly for the advanced micro-bio-loop and even can impede or halt its activity because of the

12 invasion of foreign substances related to de-oxygenation. In the advanced micro-bio-loop,

13 dissolved oxygen is progressively depleted by dark respiration of the microalgae without any

14 addition of deoxidizer, thereby creating an environmentally-stable system. This de-oxygenation method can spontaneously and rapidly generate an oxygen-free microalgae suspension, provided the retention time lasts only $2 \sim 3$ hours. This substantially reduces the capital and operational cost, the latter through a major gain in efficiency.

\subsection{Anaerobic digestion}

Conventional feedstock entering an anaerobic digester includes large organic polymers and recalcitrant materials that inevitably lower the conversion efficiency and generate inert residues of digestate (Chen et al., 2008). Owing to the absence of lignin, etc. (González-Fernández et al., 2012; Popper et al., 2011), microalgae are recognized to be an attractive substrate for anaerobic digestion, noting that microalgae produce $0.53 \sim 0.80 \mathrm{LCH}_{4}$ $\mathrm{g}^{-1}$ VS (González-Fernández et al., 2012) (i.e. liters of methane per gram volatile solids). The resultant digestate does not contain inert residues, and so can achieve full recycling whereby fertilizer is created for the microalgae culture, accordingly reducing the disposal problem. The proportion of methane in the biogas produced lies in a similar range (i.e. $60 \% \sim 75 \%$ ) to that of the majority of other microalgae-based studies related to biogas applications, regardless of species and operating conditions (Ras et al., 2011).

\subsection{Aerobic decomposition}


1 Digestate is a highly valuable fertilizer which, if used effectively, can significantly offset

2 inorganic fertilizer. However, conventional biogas production usually involves pumping

3 digestate and then spreading it on nearby land or discharging into receiving waters without

4 proper post-treatment. This practice greatly increases the risks of lake eutrophication arising

5 from $\mathrm{N}$ and $\mathrm{P}$ outputs, the spread of pathogens from one farm to another, and the release of

6 contaminants into the food chain. In the advanced micro-bio-loop, reuse of a digestate suspension to cultivate microalgae not only lowers the need for chemical fertilizer to promote microalgae production but also avoids the aforementioned risks. Moreover, water in the digestate suspension can also be re-used simultaneously in further microalgae cultivation. However, the digestate suspension contains some organically-bounded nutrients that are generally believed to be indigestible by or even toxic to the dominant microalgae species in nature (Uggetti et al., 2014). For direct feed back into the microalgae culture without pre-treatment, the resulting recycling ratio of partial nutrients will merely remain unaltered at about 50 80\% (Brennan and Owende, 2010; Golueke and Oswald, 1959). In order to achieve a more optimal recycling ratio and keep microalgae at their best, advantage is taken of aerobic bacteria mineralization to convert organic nutrients in the digestate into inorganic forms that are readily digestible by microalgae. The nutrients and water in the advanced micro-bio-loop correspond to recycling ratios that are almost always 100\%, achieving in situ quality management of the digestate. Consequently, the fertilizer cost substantially decreases from $0.012 \$ \mathrm{~kg}^{-1}$ algae year ${ }^{-1}$ to $0 \$ \mathrm{~kg}^{-1}$ algae year ${ }^{-1}$ (under $25 \mathrm{~g}$ algae $\mathrm{m}^{-2} \mathrm{~d}^{-1}$ productivity), which accounts for $30 \%$ cost and $45 \%$ effective energy of the microalgae culture (Clarens et al., 2010).

In the present study, the advanced micro-bio-loop employed naturally dominant species, i.e., aerobic and anaerobic bacteria taking from domestic sewage treatment plant, and microalgae taking from natural local lake. Tab.1 shows the mass and energy flows of the advanced micro-bio-loop with the considered functional unit of $890 \mathrm{MJ}$, produced by the combustion of $\mathrm{CH}_{4}$ in an internal combustion engine.

\section{Comparison of the advanced micro-bio-loop with conventional biogas production} from the perspective of sustainability

Life Cycle Sustainability Assessment (LCSA) is performed to analyze potential impacts of the 
1 advanced micro-bio-loop and conventional biogas production process typically on natural

2 resources, human society, economy and environment. The life time of processing

3 infrastructures is assumed to be 15 years. The advanced micro-bio-loop considered herein is

4 located in the middle of China. The relevant analysis on it is based on our experimental

5 observation and material balance. The inventory of conventional biogas production process is

6 derived from academic resources, engineering design standards, communications with

7 industrial producers, and processes described in the Ecoinvent Database. (See Supplementary

$8 \quad$ Table S1-S6)

9 Advanced micro-bio-loop and conventional biogas production process achieve a net positive energy balance at remarkably different levels, $0.0224 \mathrm{kWh} \mathrm{MJ}^{-1}$ and $0.0539 \mathrm{kWh} \mathrm{MJ}^{-1}$. The $\mathrm{C}$, $\mathrm{N}, \mathrm{P}, \mathrm{K}$, and water balances in the micro-bio-loop corresponds to recycling ratios of $103.4 \pm$ $0.5 \%, 99.8 \pm 1.9 \%, 102.7 \pm 1.1 \%, 104.2 \pm 0.9 \%$ and $99.97 \%$ respectively, achieving a free supply of fertilizer and water. Fig. 2 compares the impacts generated by producing $1 \mathrm{MJ}$ biogas using these two systems from the perspective of Life Cycle Sustainability Assessment. Each impact is standardized according to the value of the worst scenario specific to the impact. The results indicate that the micro-bio-loop is vastly preferable to conventional biogas production in terms of energy use, acidification potential, global warming potential, ozone layer depletion, eutrophication, total investment cost, water demand, arable land use, and labor. All the preceding impacts are less than $33 \%$ of conventional biogas production. The water demand of the micro-bio-loop $\left(3.66 \times 10^{-5} \mathrm{~m}^{3} \mathrm{MJ}^{-1}\right)$ is less than $0.57 \%$ of conventional biogas production $\left(6.42 \times 10^{-5} \mathrm{~m}^{3} \mathrm{MJ}^{-1}\right)$ at the same functional unit. Due to the particular feedstock and simple infrastructure inherent to the micro-bio-loop system, its requirements for arable land-use and labor are only $7.35 \%$ and $0.041 \%$ of conventional biogas production. From the above insights into technological, environmental and economic dimensions, the advanced micro-bio-loop has much competitive performances beyond an equivalent conventional biogas production system.

In China, particularly in rural areas, the enthusiasm for household biogas production schemes has waned from an initial flourish of interest, partly because of a lack of scientific management by farmers of the inputs and outputs, along with a lack of 
$1 \$ 40$ billion market potential to revitalise household biogas production and could

2 simultaneously mitigate at least 210 million tons $\mathrm{CO}_{2}$ emission over the next 5 years,

3 thereby making great contributions to China's Renewable Energy Development Plan

4 and China's National Plan for Climate Change (2016-2020) (Committee, 2007, 2014).

5 4. A more efficient improvement for the advanced micro-bio-loop industrialization

6 Vigorous aeration is required to provide sufficient $\mathrm{CO}_{2}$ for the microalgae culture and $\mathrm{O}_{2}$ for

7 aerobic decomposition (Grady Jr et al., 2011; Richmond, 2008). The associated energy

8 consumption proves to be a millstone, resulting in an operational cost increase of $20 \%$. In fact,

9 only a coupled reactor can substitute for aerators in the advanced micro-bio-loop, without

10 requiring any energy input, noting that both microalgae and aerobic bacteria exhibit a high degree of uniformity in the survival environment due to their symbiotic behavior. More precisely, microalgae produce the $\mathrm{O}_{2}$ necessary for aerobic bacteria to mineralize organic matter, consuming in turn the $\mathrm{CO}_{2}$ released by respiration of the aerobic bacteria (Praveen and Loh, 2015). According to the classical two-film theory, the $\mathrm{CO}_{2} / \mathrm{O}_{2}$ transfers involved in the microalgae culture and aerobic decomposition processes are all essentially controlled by liquid-films and gas-films (Fig. 3(a) and Fig. 3(b)). Use of a coupled reactor can completely eradicate the resistances of the four films created by microalgae culture and aerobic decomposition (Fig. 3(c)), thereby encouraging smoother exchange of $\mathrm{CO}_{2}$ and $\mathrm{O}_{2}$ and providing a mechanism for efficient mixing.

\section{Conclusions}

The advanced micro-bio-loop involves a completely independent, stable micro-ecosystem, which comprises a sustainable cycling eco-chain of producers, consumers, and decomposers (microalgae, anaerobic bacteria, and aerobic bacteria). The resulting micro-ecosystem differs to that of a conventional biogas production process in that the former simultaneously achieves full internal and external circulations of all substances. Technological simplicity combined with full circulation at steady-state operation make the advanced micro-bio-loop a particularly attractive option due to its large scale availability, tractable technology, ease of installation, safe operation, and overall economic efficiency. The advanced micro-bio-loop could 
1 progressively substitute for a significant proportion of biogas energy production

2 facilities, with significant societal benefits.

3

4

\section{Acknowledgements}

This work was supported by National Natural Science Foundation of China (21476139).

\section{References}

Ashokkumar, V., Salam, Z., Sathishkumar, P., Hadibarata, T., Yusoff, A.R.M., Ani, F.N., 2015. Exploration of fast growing Botryococcus sudeticus for upstream and downstream process in sustainable biofuels production. J. Clean. Prod. 92, 162-167.

Brennan, L., Owende, P., 2010. Biofuels from microalgae-A review of technologies for production, processing, and extractions of biofuels and co-products. Renew. Sust. Energ. Rev. 14, 557-577.

Chen, Y., Cheng, J.J., Creamer, K.S., 2008. Inhibition of anaerobic digestion process: a review. Bioresour. Technol. 99, 4044-4064.

Clarens, A.F., Resurreccion, E.P., White, M.A., Colosi, L.M., 2010. Environmental life cycle comparison of algae to other bioenergy feedstocks. Environ. Sci. Technol. 44, 1813-1819.

Committee, N.D.a.I., 2007. China's medium and long term Renewable Energy Development Plan. National Development and Innovation Committee, Beijing.

Committee, N.D.a.I., 2014. China's National Plan on Climate Change (2014-2020). National Development and Innovation Committee, Beijing.

Cuellar-Bermudez, S.P., Garcia-Perez, J.S., Rittmann, B.E., Parra-Saldivar, R., 2015. Photosynthetic bioenergy utilizing $\mathrm{CO}_{2}$ : an approach on flue gases utilization for third generation biofuels. J. Clean. Prod. 98, 53-65.

Deublein, D., Steinhauser, A., 2011. Biogas from waste and renewable resources: an introduction. John Wiley \& Sons, New Jersey.

Golueke, C.G., Oswald, W.J., 1959. Biological conversion of light energy to the chemical energy of methane. Appl. Microbiol. 7, 219-227.

González-Fernández, C., Sialve, B., Bernet, N., Steyer, J.-P., 2012. Impact of microalgae characteristics on their conversion to biofuel. Part II: Focus on biomethane production. Biofuels Bioprod. Bior. 6, 205-218.

Grady Jr, C.L., Daigger, G.T., Love, N.G., Filipe, C.D., 2011. Biological wastewater treatment, third ed. CRC Press, Florida. Jiménez, C., Cossı, amp, x, o, B.R., Niell, F.X., 2003. Relationship between physicochemical variables and productivity in open ponds for the production of Spirulina: a predictive model of algal yield. Aquaculture 221, 331-345.

Lukehurst, C.T., Frost, P., Al Seadi, T., 2010. Utilisation of digestate from biogas plants as biofertiliser. IEA Bioenergy, Paris. Luque, R., 2010. Algal biofuels: the eternal promise? Energ. Environ. Sci. 3, 254-257. Mendoza, J.L., Granados, M.R., de Godos, I., Acién, F.G., Molina, E., Heaven, S., Banks, C.J., 2013. Oxygen transfer and evolution in microalgal culture in open raceways. Bioresour. Technol. 137, 188-195. 
1 Milieuhygiëne, N.M.v.V.e., Foundation, E.M., 1989. Environmental health and pollution control.

2 Excerpta Medica Foundation, Netherlands.

3 Monari, C., Righi, S., Olsen, S.I., 2016. Greenhouse gas emissions and energy balance of biodiesel

4 production from microalgae cultivated in photobioreactors in Denmark: a life-cycle modeling. J. Clean.

5 Prod. 112, 4084-4092.

6 Popper, Z.A., Michel, G., Hervé, C., Domozych, D.S., Willats, W.G., Tuohy, M.G., Kloareg, B., Stengel,

7 D.B., 2011. Evolution and diversity of plant cell walls: from algae to flowering plants. Annu. Rev. Plant

8 biol. 62, 567-590.

9 Praveen, P., Loh, K.C., 2015. Photosynthetic aeration in biological wastewater treatment using

10 immobilized microalgae-bacteria symbiosis. Appl. Microbiol. Biotechnol. 99, 10345-10354.

11 Ras, M., Lardon, L., Bruno, S., Bernet, N., Steyer, J.-P., 2011. Experimental study on a coupled process of production and anaerobic digestion of Chlorella vulgaris. Bioresour. Technol. 102, 200-206. Richmond, A., 2008. Handbook of Microalgal Culture: Biotechnology and Applied Phycology. John Wiley \& Sons, New Jersey. Uggetti, E., Sialve, B., Latrille, E., Steyer, J.P., 2014. Anaerobic digestate as substrate for microalgae culture: The role of ammonium concentration on the microalgae productivity. Bioresour. Technol. 152, 437-443. 


\section{Figure captions}

Fig. 1 Schematic diagrams of: (a) conventional biogas production process; and (b) advanced micro-bio-loop.

Fig. 2 Comparison of impacts generated by production of $1 \mathrm{MJ}$ biogas using the conventional biogas production system and the advanced micro-bio-loop. The labels GWP, AP, EP, ODP, Arable land, Water, Labour, and Expense refer to global warming potential, acidification potential, eutrophication potential, ozone depletion, arable land use, water consumption, labour cost, and total investment.

Fig. 3 Two-film theory models of: (a) microalgae culture; (b) aerobic bacteria culture; and (c) microalgae coupled to aerobic bacteria culture. 
Table 1 Mass and energy flows of the advanced micro-bio-loop with the functional unit of $890 \mathrm{MJ}$

\begin{tabular}{|c|c|c|c|}
\hline Type & Description & Quantity & Units \\
\hline \multicolumn{4}{|c|}{ Operation 1: microalgae culture } \\
\hline Output & Flow out of the photo-bioreactor & 310.288 & $\mathrm{~m}^{3}$ \\
\hline Input & Mineralized digestate (contains inorganic N, $\mathrm{P}$ and $\mathrm{K}$ ) & 310.254 & $\mathrm{~m}^{3}$ \\
\hline Input & $\mathrm{N}$ & 0.000 & $\mathrm{~kg}$ \\
\hline Input & $\mathrm{P}$ & 0.000 & $\mathrm{~kg}$ \\
\hline Input & $\mathrm{K}$ & 0.000 & $\mathrm{~kg}$ \\
\hline Input & Water & 0.0325 & $m^{3}$ \\
\hline Input & Electricity consumption (air pump) & 1.310 & $\mathrm{kWh}$ \\
\hline Input & Electricity consumption (pumping) & 0.873 & $\mathrm{kWh}$ \\
\hline \multicolumn{4}{|c|}{ Operation 2: de-oxygenation } \\
\hline Output & Flow out of the de-oxygenation plant & 310.288 & $\mathrm{~m}^{3}$ \\
\hline Input & Flow out of the photo-bioreactor & 310.288 & $\mathrm{~m}^{3}$ \\
\hline Input & Electricity consumption (pumping) & 3.939 & $\mathrm{kWh}$ \\
\hline \multicolumn{4}{|c|}{ Operation 3: anaerobic digestion } \\
\hline Output & Biogas $\left(70 \% \mathrm{CH}_{4}\right)$ & 32.250 & $\mathrm{~m}^{3}$ \\
\hline Output & Digestate (contains organic N, P and K) & 310.254 & $\mathrm{~m}^{3}$ \\
\hline Input & Electricity consumption (pumping) & 3.939 & $\mathrm{kWh}$ \\
\hline Input & Heat consumption (internal biogas) & 2.047 & $\mathrm{kWh}$ \\
\hline Input & Flow out of the de-oxygenation plant & 310.288 & $\mathrm{~m}^{3}$ \\
\hline \multicolumn{4}{|c|}{ Operation 4: aerobic decomposition } \\
\hline Output & Mineralized digestate (contains inorganic N, P and K) & 310.254 & $\mathrm{~m}^{3}$ \\
\hline Input & Digestate & 310.254 & $\mathrm{~m}^{3}$ \\
\hline Input & Electricity consumption (air pump) & 1.310 & $\mathrm{kWh}$ \\
\hline Input & Electricity consumption (pumping) & 0.873 & $\mathrm{kWh}$ \\
\hline \multicolumn{4}{|c|}{ Operation 5: purification } \\
\hline Output & Methane, $96 \%$ & 22.575 & $\mathrm{~m}^{3}$ \\
\hline Input & Biogas $\left(70 \% \mathrm{CH}_{4}\right)$ & 32.250 & $\mathrm{~m}^{3}$ \\
\hline Input & Electricity consumption & 4.291 & $\mathrm{kWh}$ \\
\hline \multicolumn{4}{|c|}{ Operation 6: combustion } \\
\hline Output & Energy (from methane) & 172.000 & $\mathrm{kWh}$ \\
\hline Input & Methane, 96\% & 22.575 & $\mathrm{~m}^{3}$ \\
\hline
\end{tabular}




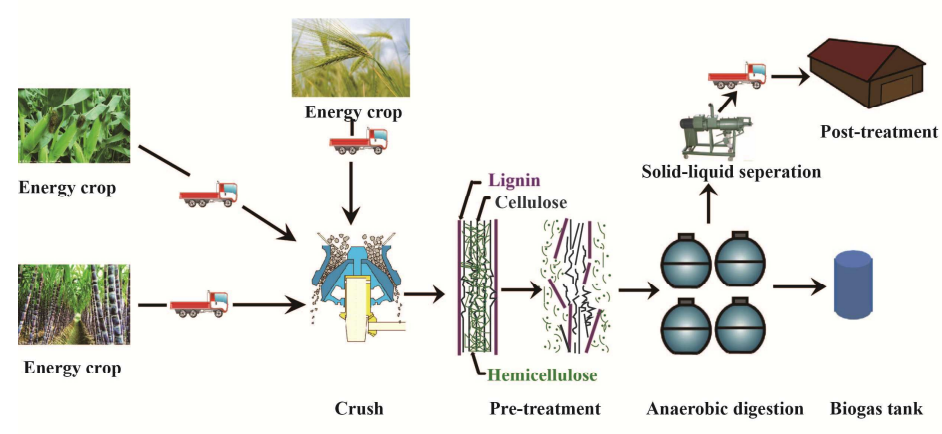

(a)

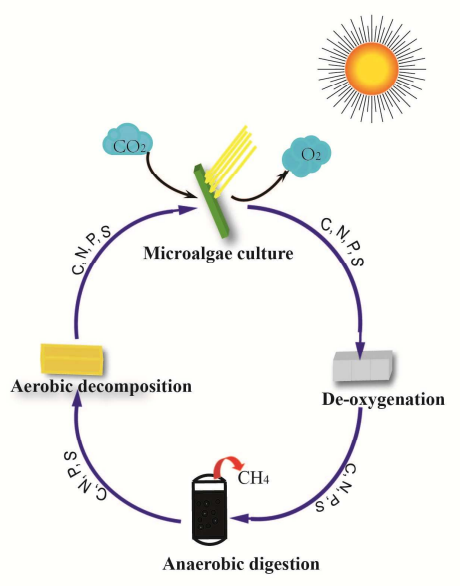

(b)

Fig. 1 Schematic diagrams of: (a) conventional biogas production process; and (b) advanced micro-bio-loop. 


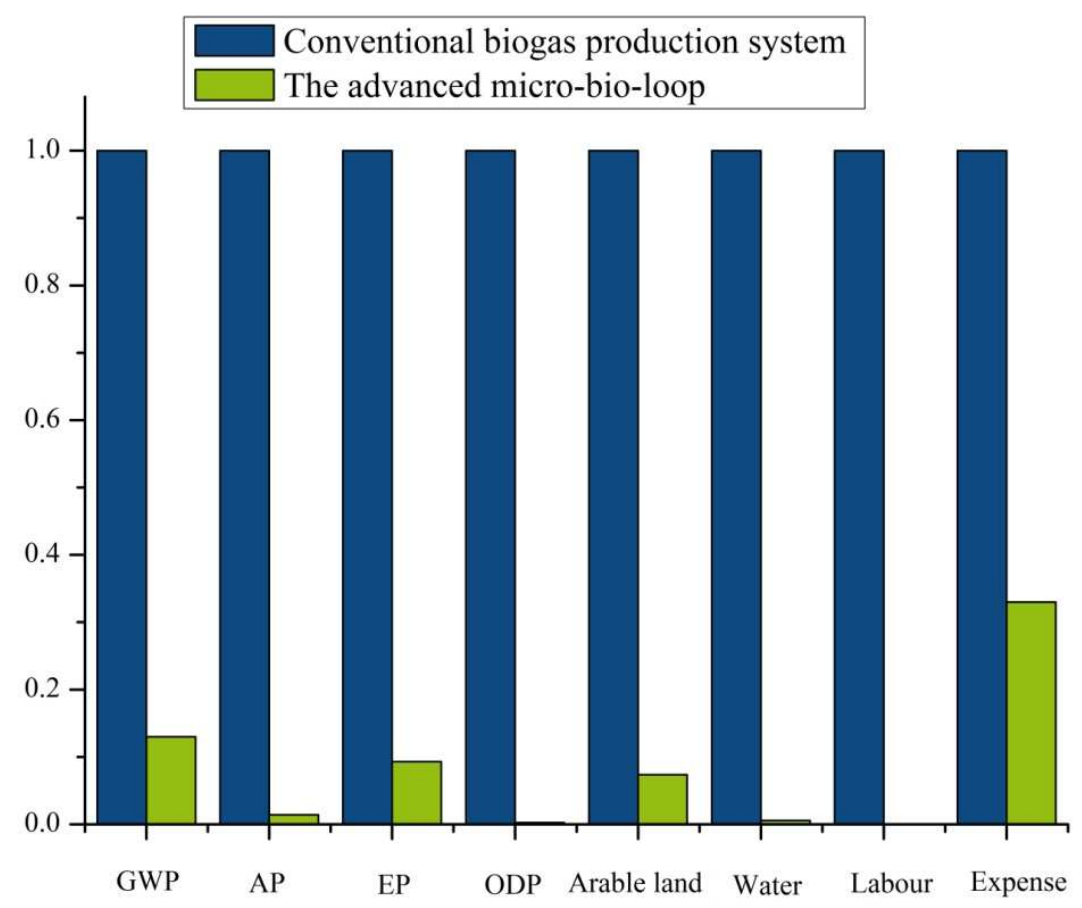

Fig. 2 Comparison of impacts generated by production of 1 MJ biogas using the conventional biogas production system and the advanced micro-bio-loop. The labels GWP, AP, EP, ODP, Arable land, Water, Labour, and Expense refer to global warming potential, acidification potential, eutrophication potential, ozone depletion, arable land use, water consumption, labour cost, and total investment. 


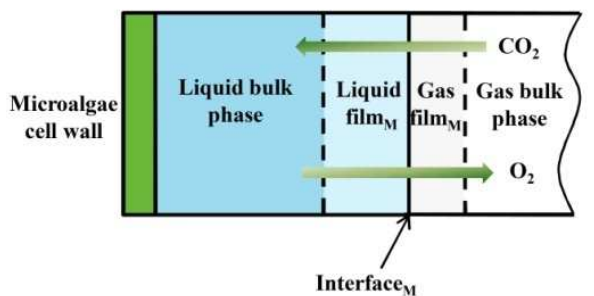

(a)

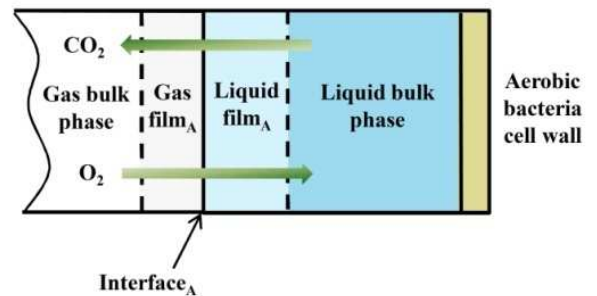

(b)

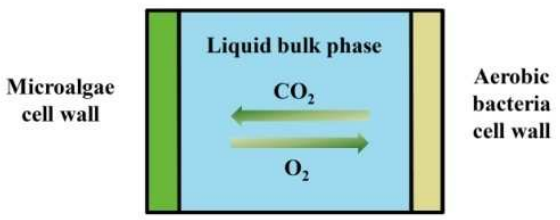

(c)

Fig. 3 Two-film theory models of: (a) microalgae culture; (b) aerobic bacteria culture; and (c) microalgae coupled to aerobic bacteria culture. 